\title{
THE LIMITS OF SENSUALITY: PASTORAL WILDERNESSES, TASSO'S AMINTA AND THE GARDENS OF FERRARA
}

At the Renaissance courts of the Estes, playwrights, landscape architects and artists developed new forms and vocabularies for portraying the landscape. Pastoral drama, frescoes, tapestries, theatrical scenery, elaborate gardens showed a broad range of powers shaping scenery to ornament life in Ferrara, and in the Este villas at Tivoli and in Rome.

Control over the unruly was often the theme of these design. Their chief antique models were Ovid, who laid the entire mythological and historical world at the feet of Augustus, and Virgil, who showed both informal and agricultural landscapes within the Emperor's sway. Updating such imagery to Renaissance Ferrara, lines from the Eclogues flattered the ruling prince as a new Augustus, and gardens turned actual sites into illustrations of the Metamorphoses: 1

Contrasts between civilized and rustic scenes gave drama to landscapes that ultimately celebrated the advantages of temperate rule over self and society. Drawing on ancient and modern models that transformed struggles in exotic locations into entertaining prospects, artists working in gardens and theatres moved beyond the neat geometrical formulas inherited from the cloister garden and the comfortable setting of the eclogue. ${ }^{2}$ The newer, more complex landscapes of Ferrara expressed confidence in order by treating extensively once dangerous material - forests, cliffs, passions, frustrations, peasants and satyrs - with ease, humor and the control of "a lavish and festive style."' ${ }^{3}$ Perspective, sophisticated technology for fountains in gardens, classical statues and topiary displayed in even the most irregular garden the power to tame the natural rhythms of the landscape as literary allusions, classical poses and scenery in the theatre suggested a discipline superior to the wild emotions of the characters. Combining extravagant landscapes and rustics, dramatists in Ferrara worked out some of the most successful designs for the pastoral, which found one of its best forms in the Aminta, widely imitated, translated and parodied.

The following pages argue that Tasso designed the Aminta to lead from the folly of passionate hyperboles to the pleasures of 
moderation. By showing how Tasso's changes in his classical sources conform to critical readings of temperance in the classical models for the pastoral and by comparing his designs of scenery with the mock wildernesses of Este gardens that he mentioned in the play, the paper suggests that larger contexts supporting right rule dominate the wild and sensual moments in the Aminta. Ironies, symmetries, allusions keep in their subject place alternatives to good order such as satyrs and shepherds, the passionate and the extreme, the private and separate. By these devices Tasso established the distance that Hallett Smith noted as the discrepancy between the vision of the pastoral characters and that of the sophisticated audience. ${ }^{4}$ Although Tasso subtly provided lines for a range of reactions from scorn to sympathy, his method ultimately directs attention to the manner of presentation and flatters the audience's superior wisdom. Shifting scenes and attitudes, literary reverberations and landscape perspectives, elegance of design and ornaments in style prevent a simplistic entanglement with the emotions of the characters.

Concentrating on two of the principal contexts of Tasso's drama as keys to his affectedly simple designs, this paper has three parts. The first section focuses on Renaissance interpreters' discovery of arguments for right rule in the classical sources of pastoral drama and shows how Tasso's adaptations of material from Achilles Tatius' novel similarly emphasize virtue rather than indulgence. The second studies the artificial mountain in Ferrara and the Belvedere (which Tasso mentions in his play and where it was first performed) in order to show how his seemingly savage scenery is, like the wildernesses of these gardens, contained within a larger plot leading to the triumph of good order. The third and major section analyzes the designs of scenery in the Aminta, as well as its choruses, geometries in plot and allusions in language, prologue and epilogue, intermedii, references to Ferrara and its courtiers that remind the audience of other contexts beyond the plights and antics of the characters. These amplifying structures, sometimes by implication and sometimes directly, affirm the need for moderations of desire, of words and of actions.

Despite early observers' evaluations of the Aminta as a celebration of restraint, major criticism of the play for almost two centuries has concentrated principally on its images of sensuality and romantic love. The play has recently seemed a revolt against 
convention, and its scenery especially has seemed deliciously uninhibited. Writing in a period when poetic as well as landscaping style affirmed the value of the naturalistic scene and the assertive individual rather than the geometrical and mythological unities of the Italian tradition, many modern critics interpreted the scenery of the Aminta as luxurious in both theme and technique. ${ }^{5}$ Yet, the play has many more horrors and troubles than pleasures in its mock-natural landscape: attempted rape, attack by wolves, spurned kisses, despair and attempted suicide, discovery of affection only when it seems too late to reciprocate. As in the Metamorphoses, these scenes of wanton struggle and cruelty brought to a happy conclusion show that only right rule by reason, prince and artist can solve problems. This communal ending blends together many other worlds in its combination of Cupid's power, the blessings of father, the promise of playing children.

Early commentators, recognizing the discipline of style successfully controlling the extravagance of material, heard in the Aminta graceful restraint rather than decadence. Traiano Boccalini pointed to "l'inesausta moltitudine di tanti elegantissimi concetti, conditi con le più eleganti frase, e modi soavissimi di dire." In 1621 Tasso's first biographer, G. B. Manso, described the play as "regolatissima" and "secondo l'vniuersali, \& antiche regole della poetica composto." Literary innovations all'antica, such as the choruses and the pragmatographias, helped orient the audience to an overview based on style rather than participation in the foolish and rustic sentiments of the characters. ${ }^{6}$

\section{Classical Sources of the Pastoral}

Renaissance commentators interpreted the classical sources of the pastoral and artists imitated such models in order to emphasize current ideals of order and the actual experiences of power in action. These readers saw in the licentious and savage scenes of ancient drama arguments in praise of rational rule. Similarly, Tasso changed titillatingly erotic passages in his sources into narrations that underscore the frustrations rather than the pleasures of love. Especially for early performances, his manipulations of a newly-translated novel shifted attention from the plight of the characters to his literary craft.

Many Renaissance writers acknowledged Euripides' Cyclops 
and Plautus' Amphitruo as important dramatic models for the pastoral.' In the first, Odysseus skillfully extricates himself and some of his men from the clutches of Polyphemus; in the second, Jupiter commits adultery with the wife of Amphitryon and appeases the husband by promising that the coming child will be renowned. These plays that include so much boasting, violence, caprice, self-assertiveness would seem to support those critical readings of the pastoral as a genre devoted to the expression of private and rebellious passions. In his modern introduction to the Cyclops, Arthur S. Way asserts that "the unrestrained license of the original Dionysia found here its literary expression."

However, to sixteenth-century commentators, rather than joyful emancipation from morality, the Cyclops illustrated the disorders and pains of a world in which rule has gone awry. Casaubon read it as a moral fable named, as in other Greek plays, after the justly-disgraced character. Gaspar Stiblinus' commentary on the play interpreted it as an example of personal and social excesses, partly derived from Homer's model where the Cyclops "uterque autem fingit vastum corpore crudelem, divorum contemporum, inhospitalem, voluptuarium." $\mathrm{He}$ continued by arguing that Euripides' play provides an image of barbaric life, which neither laws nor civil discipline restrains, nor religion governs. In this reading, Euripides presented these crimes in order to excite men to culture and the fullness of living with greater reason. Accordingly, the monster becomes a figure for life without rules and lived solely for lust, of living for the body rather than the mind. So interpreted, the Cyclops provided a warning that encouraged readers to study arts, discipline, justice and to be reverent to the laws. ${ }^{9}$

Stiblinus extended the personal allegory into a politcal one. In this, the Cyclops is an image of a tyrant who lives as he pleases and whose own libido is his law. "Praeterea tyranni imaginem licet videre in Cyclope, cui quot libet licet." 10 So explained, the Cyclops' rule presents the darker side of the uninhibited desires ("cuique propria libido pro lege est") that the first Chorus of the Aminta pictures in the golden age where "S'ei piace, ei lice" (1.590). The drunkeness of the Cyclops, like his blindness, reveals physically his moral condition. Thus, he was a useful model combining the voluptuous man and the tyrant. Stiblinus both scorned and condemned him as "ridiculus ac ebrius ... mores, 
ineptias." In contrast, Ulysses was an illustration of the highest prudence, a leader whose resolution and ingenuity in saving his men invites comparison with the examples in Cicero's essay on fortitude. ${ }^{11}$

The other major classical dramatic source of the pastoral is similarly instructive in princely and personal virtue. Jupiter reconciles Amphitryon to cuckoldry by recommending "sua virtù serena" and the promise of glory, respect, even worship, for the son to be born. Anyone in authority might like Amphitryon's response, "io faro tutto ciò che me commandi," which might seem a parody of power in action. But the commentator in the 1566 Antwerp edition saw that Jove, like the prince, could turn grief to joy. An English critic concluded that the subject of "this most noble of all the Comedies of the Ancients" is "the Honour of Jupiter" and that in Rome "it was commonly Acted in Times of publick Troubles and Calamities, to appease his Anger." 12

Renaissance commentators consistently read in these sources arguments for good order in the calculated reserve of Odysseus who led his men out of danger and in the assuaging power of Jove who converted wrath into the happy promise of Hercules' birth. Such interpretations were consistent with traditional morality as well as the optimistic self-images if not the realities of the political communities in which pastorals were performed. The right exercise of power brought the greatest benefits; there was little notice of the cost in private pleasures that this system required and considerable praise of the virtuous discipline that made civilized society possible.

Similarly, Tasso's use of his classical sources conformed to the specifications of these interpretations which argue for patience, temperance, the necessity of rules, order and good government. He converted explicitly sensual passages, for example, from Achilles Tatius' Clitophon and Leucippe in order to make them emphasize the chastity of the heroine. ${ }^{13}$ In the first book of the novel, Clitophon, standing in a lush garden of entwined trees, flowers and singing birds, and seeing that his beloved is in earshot, talks with his servant about how all of the elements of nature arrange themselves into loving pairs. As he rambles through his list, he watches her reaction and is pleased that she is attentive, even interested. In the Aminta (1.2, 122-66), however, Tasso gave the boy's lines to an older woman whose images of natural affection the heroine mocks 
before going off to a hunt rather than to an assignation. ${ }^{14}$ Second, Tasso changed the scene in the novel in which Clitophon, having observed Leucippe kiss the hand of a servant stung by a bee, pretends to have been stung on the lips. They kiss agreeably and often and would have continued but a servant approaches and interrupts them; within seven chapters the lovers are in bed, brief though their moment there is. In the Aminta this device to steal a kiss occurs in a lamentation by Aminta who, trying the same ruse, has his affection discovered. Silvia rebukes him for it. Thus Tasso turned the scene from a delightful moment to one which reinforces her exaggeratedly chaste image. ${ }^{15}$ While enriching the literary dimensions of the play and drawing the observer from mere attention to the surface events, these scenes also bring humor into the service of conventional morality. By extending the ironic attitude toward sensuality and other absurd behavior available in his sources, Tasso increased the moral seriousness of his material.

\section{The Gardens of Ferrara}

Like the seemingly licentious designs of the satyr play which Renaissance interpreters used to illustrate praise of order, the gardens of Ferrara displayed extensive images of disorder within larger patterns of control. Rather than the simple Medicean assertion of hilltop forts like Poggio a Caiano or the geometries of the Boboli, garden grottoes and wildernesses displayed early in the Cinquecento for the princes of Ferrara once dangerous scenes as ornaments in elegant compositions. ${ }^{16}$ Such sites provided for early audiences of the Aminta settings in which the ferocious energies of nature were exhibited and tamed as passion was in the pastoral.

Tasso's playful and surprising conversion of the lofty precipice from which Aminta leaps into the friendly retreat of Elpino is a design that is similar to one used in the most startling garden ornaments in Ferrara: the mock mountains which various Este princes erected, sometimes with dirt from the excavations for the moats of the city. A contemporary illustration of the largest of these hills shows the sides planted with trees in quincunxes to image a wilderness within the gardens of San Giorgio. Through these groves a path winds up to a surmounting pavilion from which visitors survey those below in the turmoil of earthly life. ${ }^{17}$ Such imagery, readily available from Poliphilius' climb up a mount 
with Logistica in the Hypnerotomachia that enabled Poliphilius to look over the labyrinth of life, ${ }^{18}$ has a secular meaning reversing Petrarch's estimate of the vanity of his climb up Mt. Ventoux. The moral superiority of the lofty stance, separate and observing, organizes the physical world into the limits of its own focus. Like the perspectives and axes of the villa, the perception of ingenious design illustrates the superiority of wisdom and that recognizes over-all pattern and thus judges the whole, not parts. An observer of the Montagna di San Giorgio noted the artistic human hand in it: "una gran Montagna artificiosamente fabbricata." Placed about the slopes were reminders of order even within the mock quincuncial wilderness: rooms with grotteschi and mosaics, pictures and "vaghissimi ed ombrosi pergolati di varie viti coperte, ed altre verdure." 19

One of the principal Ferrarese gardens was the island retreat of the Belvedere, where the court first saw the Aminta and to which Tasso referred within the play. ${ }^{20}$ Secret fountains, including a metal tree (like Chatsworth's), sprayed water on unwary visitors at the direction of the prince. Such pranks put a premium on prudence, an awareness of the whole scene (rather than moving rashly through it), and they also demonstrated in an intimate way the ruler's dominion over the environment of the court. Agostino Faustini described the garden's lozenge shape encircled with a skillfully-painted wall. The palace of the prince flanked by the subordinate house of his steward and of his bailiff, provided the focus of the garden plot. From the ruler's house led axes to other architectural markers: pavilions, a fountain, a ball court, and a tower for pigeons. Schrader noted even the surrounding selvaggio, in which were scenes drawn from the Metamorphoses, "in quincuncem dispositus." ${ }_{21}$ In such gardens it would have been difficult to forget even for a moment the authority that controlled the scene by means of talent, learning, money and tricks.

\section{Tasso's Aminta}

Consistent with the architectural definition of savage garden landscapes and with the use of classical satyr drama to bolster up praise of prudence and good government, pastoral dramas in Ferrara include antique lines, choruses and symmetries that break through the illusion of raw passion to remind the audience of 
ultimate moral and political frames on experience. By the end of the sixteenth century interpretations of the pastoral drama become so important that commentary takes up a third or more of the printed editions. ${ }^{22}$

There was a high tolerance for disparate materials which diminished the power of the superificially simple pastoral pretence. Even engravings combined rustic and civilized buildings and so carried into the printed texts repeated reminders of stylishly superior vocabularies. Illustrators resisted the chaste example of Vitruvius' satyric scene, composed entirely of trees and shrubs. Rather than this simple verdure, Serlio showed rustic huts in a grove. In the authoritative 1590 edition of the Aminta, the illustrations are within heavy frames with playful mannerist forms: cartouches, grotteschi, columns sliding into carytids. The engraving for the prologue includes an allée, arbor, loggia, canal, parterre and obelisk, casino, fountain. For the chorus on the golden age and for the final chorus, identical pictures show a water wheel and peasant hut, a bridge, a pavilion with pediment. ${ }^{23}$ These additions of elegant modern garden and architectural pieces to Tasso's scene inspire complex associations that the audience, though hardly the characters, might appreciate.

There is about these illustrations and their pastorals the quality of a private joke that invites the viewer to smile knowingly at the witty joinings of materials from so many places, ancient and modern, courtly and peasant. The effect is similar to that raised by what Wilkinson called Ovid's "ironical affection of naiveté." ${ }^{24}$ Such mocking attitudes and their methods shift attention from the subject to the manner of presentation and especially to manipulation of illusion and pose. Through such designs, these plays support the traditional aristocratic concern for ornament and style as proof of the observer's superiority to the observed and especially lead the audience to see the action in the larger perspectives of landscapes and myths.

This assessment of the pastoral's confidence in controlling multiple and divisive visions within a unifying focus especially fits the ebullient moods and self-satisfied images of both Tasso and the late sixteenth century court of Alfonso II. Tasso was, at the moment of writing the play, the most favored of court poets; he had his reward for no other service than writing, whereas his rivals had to perform other household tasks. ${ }^{23}$ The Aminta is one of the 
first entertainments staged after the terrible earthquake of 1570 , and the play commenced the optimistic and extravagant shows with which Alfonso II attempted to fortify the power of his family before its collapse in 1597, and he even seems to have specified parts he wanted in the play. ${ }^{26}$ Suiting Tasso's confident tone and his play's conclusion in moderation smiling at excess, the Gelosi, a dramatic company noted for the performance of comedies, first presented the play at the Belevedere. ${ }^{27}$ Later writers continued the good spirits of Tasso's play not only in Guarini's imitations, which invited literary comparisons, but also in explicitly humorous forms such as Ongaro's L'Alceo (the Aminta bagnato) and Pellicari's Figliuoli di Aminta e Silvia, in which a mock dynasty of pastoral characters carry on the antics of the original. The swift changes of scene, careful descriptions, long narrations, parody of sources join these to the "sweet, witty soul of Ovid." Consistent in all is scorn for the inept, the exaggerated, the unrestrained. Thus, all these plays by statement or implication celebrate good government.

Tasso was the first pastoral dramatist to make verbal scenery ironic and a major element in supporting a dramatic argument for temperance. Fully-developed landscape settings were unusual in earlier Italian plays. Both Politian and Cinthio used merely short, descriptive notes and metaphors. Tasso expanded such elements into a major unifying device. Like the gardens of Ferrara, the locations of the Aminta often rely on the Metamorphoses and begin in mythology. In her attempts to woo Silvia to love Aminta, Dafne describes a zoo of animals - tigers, adders, nightingales, horses - that come together, and then, in imitation of Ovid, she provides a nursery catalogue of trees which "l'un per l'altro ... arde e sospira" (1.1. 156). Silvia deflates this golden-age scene when she mockingly replies that she'll be in love when she can hear the plants sighing for each other. In an angry retort, Dafne describes a scene in hell, antithetical to the one of communion which she has just finished. The symmetry of the panels is obvious, as is the self-consciously literary quality of both: the scenes are set pieces put into new verse forms. To make the hell, Tasso borrowed from Ariosto's comic description (Orlando Furioso, 34.11), blending theology and secular love theory into the infernal punishment of unresponsive women. Ariosto set his scene within the context of Astolfo's fantastic voyage to the moon. Tasso's lines inherit from this comic source the associations which not only suit 
the playful dialogue between the experienced and inexperienced women but also provide literary and moral contexts beyond the ken of the speakers. The contrast between the grand punishment of hell and the small-scale courtly fault provides a comic discrepancy that resembles other jarring elements throughout both epic and pastoral. Silvia points up the hyperbole by her annoyance and need to get back to work: "Io qui trapasso il tempo ragionando" (1.1 232).

Tasso also used this pattern of symmetrical hyperboles with elegant associations in order to connect separate scenes. In the second act, Tirsi and Aminta both describe landscapes to illustrate the superlative quality of their zeal. Tirsi, imitating Virgil's praise (Eclogues, 1. 6-8) of Augustus, addresses his patro as Pan, who in his comfortable and well-ordered land has given the poet leisure to sing. Tirsi concludes with a grand resolve to be loyal until nature reverses itself:

che d'aria pasceransi in aria i cervi e che, mutando i fiumi e letto e corso, il Perso bea la Sona, il Gallo il Tigre

(2.2 298-300)

As sources for these lines the audience might most readily hear Virgil's list (Eclogues 8.51) beginning "Nunc et ovis ultro fugiat lupus" as well as Politian's image in his Orfeo of streams that would flow backward to see the beauty of Eurydice. ${ }^{28}$ Tasso had already in the Aminta recalled such reversals when Silvia protested that she would love only when "torneranno i fiumi / e le lor fonti, e i lupi fuggiranno / da gli agni"' (1.1. 43-45). The play eventually proves the folly of such unnatural resolves, for Silvia comes to love by the end. On a smaller scale and within the scene in which Tirsi protests his extraordinary loyalty, Dafne sharply summons him back to business in the real world, "Oh, tu vai alto!, orsù, discendi un poco / a'l proposito nostro"' (2.2 301-02).

Like dominoes standing in a row, Dafne's hyperboles fall before Silvia's scorn, Tirsi's before Dafne's, and Aminta's before Tirsi's. In a catalogue of ferocious scenes (2.3 323-32, 339-42), Aminta boasts that he will brave any place to rescue Silvia. Tirsi collapses the hyperboles by confronting them with a realistic proposition: Silvia, naked and alone, is waiting for Aminta by a 
spring in the forest. Although the boy has just announced his courage in the face of imaginary woods, lions, beasts, rapid torrents, great snows, even the fires of hell, he is afraid to take advantage of the invitation and needs to be coaxed even to remain with Tirsi to talk about it.

Landscape designs most emphatically support this mocking of disproportionate passions in the characters during the last half of the play. There the wildest actions are contained within a pair of settings each described from two points of view; in each pair, the first picture, hysterical and erroneous, is replaced by a second, which is correct, calm and measured. In the first of the final topographias, Silvia pursues the wolf into the woods, is in turn pursued and leaves behind her bloody scarf. Tasso was borrowing from Ovid's story of Pyramus and Thisbe (Metamorphoses, 4. 55166.) and shifted the focus from the elegant stasis of the mulberry tree to the frenzied movements of the lovers in order to emphasize the folly of extreme reactions. Hearing in Nerina's sad description of Silvia's apparent death, Aminta rushes from the scene to kill himself. But the audience soon learns that his emotional response, in the manner of Pyramus, is unnecessary, for the next scene opens with Silvia merrily telling of her escape. Ovid used comic metaphors and lurches of diction (Pyramus' blood spouts forth like water from a broken pipe) appropriate to the Bacchic orgy in which the story is told, but Tasso figured the hyperboles principally in extravagant landscapes and in narrated action rather than in the lover's words. Silvia's description redesigns the lonely woods, seven wolves, desperate fears of Nerina's first version by putting the dangers within the orderly frame of a satisfying ending (4.1 13-49).

Using a similar pattern of contrasting descriptions, Tasso concluded the play with an emotional crescendo which ends again in the collapse of its hyperboles into the detached and orderly observations of a calm narrator. Indeed, Tasso piled hyperbole on hyperbole. Hearing of Aminta's self-wounding, Silvia finally decides to love him and, to prove her ardor, to kill herself after she has buried his body. The symmetry of her unnecessary decision with his makes obvious the comic effect of a lover's resolution to die by doubling the humorous conflict between youthful resolves and their lack of fulfillment. The Chorus even reminds the audience of the device: "È uso ed arte / di ciascun ch'ama 
minacciarsi morte: / ma rade volte poi segue l'effetto" (3.1 13234). Ingegneri observed that desperate lovers committing suicide "induce più tosto riso che compassione." 29

The final landscape is the play's most perilous and is made spatially vivid, the design of hyperboles so absurdly lofty that they fall down, somewhat bruised, to more ordinary modes of life. Ergasto describes being taken by Aminta,

... Ov'è scosceso il colle ed u'per balzi e per dirupi incolti, strada non già, ché non v’è strada alcuna, ma cala un precipizio in una valle

(4.2 209-12)

To the Virgilian echos from Damon's resolve to hurl himself "de montis in undas" (Eclogues. 8.57-58), Tasso added reminders of earlier scenes: Aminta recalls the wolves he thinks devoured Silvia and regrets that he cannot share the exit with her. After invoking a humorously alliterative quartet of garden pods (Pan, Pales, Pomona, Priapus), he jumps. Tasso even out-Ovided Ovid in repeating the scarf motif. Ergasto tries to hold back Aminta when he leaps but only catches a silk scarf which gives way.

In the Aminta, the discrepancies between the character's vision of fragments and the audience's of connections are part of a consistent pattern. To the many peripeteias earlier in the play, the fifth act adds another in Elpino's long narration which reverses the image of the previous scene. Rather than from above, which provided Ergasto's viewpoint and which had turned him "di ghiaccio" (4.2. 250), Elpino describes the hillside from down below. Thus he continues the play's sequence of mocking hyperboles and the limited vision they represent by exposing them to the ordinary and down to earth. Rather than a fearful precipice, the setting is for Elpino the site of his homey cave and pleasant conversation with a friend. The place even catches the tumbling Aminta in a safety net "d'erbe e di spini / e d'altri rami strettamente giunti" (5.1. 70-71). Thus, once again, there is no death, no need for extreme reactions, and the past becomes only "una dolente imagine di morte" (5.1 39). Tasso concluded the series of hyperboles by relaxing the characters into a pleasant here and now and the settled geometries of reason and convention..$^{30}$ 
Only the audience can fully appreciate the moderation. The lovers naively remain extremists: for example, falling on Aminta, the absolutely chaste Silvia lurches suddenly into a passionate embrace, "in guisa di baccante" (5.1. 102).

Into Elpino's calm and festive description of the final landscape, Tasso worked a single line from the Purgatorio (7.68) "dove la costa face di sé grembo" (5.1. 60). Dante's line opens the description of the lush but unsatisfactory pleasance in which dwell rulers who were negligent. The line recalls those who ruled themselves carelessly and thus lived in a world of flaws, extreme reactions and misjudgments. Like other quotations in the verse, this one establishes antique, learned and moral designs beyond the limited vision of the shepherds.

Just as he provided larger contexts through literary allusions so Tasso at the end of the play returned the characters from isolation in the wilderness of passion to the ordered world of society. Refining the wild, independent decisions that Silvia and Aminta made on their own, Elpino is on a conventional social errand to get permission from Silvia's father for the union of the lovers. The Chorus neatly reminds the audience of the decorum of their ages, of their gentle blood, of their wishes, and then draws the sequence of the affair into a scene of harmony ruled by Montano (Silvia's father), who will assemble his grandchildren around him (5.1 49-53). Greg complained of the remarkable brevity of the fifth act and Menagio of its lack of sensual vividness since the principal characters do not even appear in it. ${ }^{31}$ But Tasso ended the play with the detachment which the narration of an uninvolved character provides and thus was consistent with his pattern of de-emphasizing sensuality. Supported throughout the play by ironies and surprises that imply the advantages of settled order, this conclusion can be brief. Tasso's confidence here resembles that of garden designers in his time in Ferrara who were notable for devoting so large a portion of their gardens to images of a controlled wilderness rather than to explicit geometries.

Then, too, like the pergolas, fountains, and statues that marked princely power even in the midst of the mock forests on the Montagna and on the Belvedere, Tasso included strong voices in the play to repeat recommendations about the comfort of order and moderation despite the lovely frenzy of the central characters. Scattered like the noble buildings in the 1590 illustrations of the 
Aminta's pastoral scenes are references flattering to the court whose ruler is a god with a divine family and to his great city on the shores of the Po. The play also reminds the audience of court poets, new Linuses or Orpheuses, who join the golden present to the mythic worlds of the past. ${ }^{32}$

Dafne, Tirsi and the Chorus are characters situated like the audience as observers; all counsel moderation and accommodation to basic realities rather than the grand, mock-heroic gestures of Aminta and Silvia. Dafne, as Marvin Herrick suggested, recommends that Silvia "relax her confirmed virginity." ${ }^{33}$ Tirsi advises Aminta to get another girl.

After the first performances in which there were only choruses for the first and for the fifth act, Tasso added one for each of the remaining acts to resolutely mark throughout the play the reminders of a reasonable order. These choruses recommend loving without the affection of honor as befits ordinary people (1), loving without the affection of Platonic learning (2), loving without the affection of suicidal resolves (3), loving without madness (4), and conclude that loving simply is best (5):

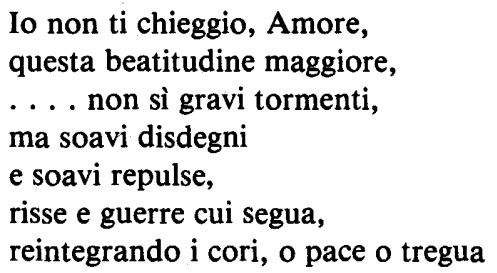

(5.1 147-48, 154-58)

Ingegneri observed that dramas use choruses to instruct and improve the audience; the Aminta concludes to reintegrando which supports the social harmony of regular life in contrast to the heroic isolation of the lovers. By the end of the play, Silvia and Aminta move from the edge of the action and the audience returns, as in all well-made gardens, to the image of order in the chorus' celebration of harmony. The comic contrariness by which despair leads to sympathy and suicide to resurrection deflates hyperboles and makes welcome the prayer for moderation. ${ }^{34}$

Further, Tasso ordered the play within the walls of a mythological skit that partly diminishes love to the silly results of Cupid's pranks. The prologue shows Cupid as a naughty boy, 
annoyed by a spanking that his mother gave him and resolved to hide out in the simple world of the play. Some editions continue this overplot into an epilogue where Venus, like a concerned housewife and mother, comes to search for her son among the audience..$^{35}$ Hardly the frames for tragedy or melancholy, these suit well the comic playfulness of the Aminta by turning the divine figures of mythology into "just folks" with very ordinary domestic concerns. This diversity of forms and styles by which a goddess is motherly and a shepherd nobly chaste enriches the play's characterizations. Many roles are unstable and shifting: Aminta resembles both Pyramus and Orpheus, Tirsi sounds like Orpheus and Tasso, Dafne is both poignant in her reflections on lost youth and Pandarus-like, Love is both universal ordering force and petulant child, poets both ideal (1.2 536) and false (1.2. 458), the court a place of evil (1.2 461-65) and good (2.2 271-300). Tasso's contrasts and complexities such as those between sympathy and humor achieve a balance by the end of the play suitable to the theme of moderation that the chorus articulates. These ambiguities are suggestive and may have voiced his society's dissatisfaction with restraints. Yet those long accustomed to courtly conventions, to the moral and theological rightness of strict rule, to the inevitable compromises that economics and politics imposed on love, would have had to work hard to discover rebellious passion triumphant in the play.

Finally, Tasso's designs, as his earliest commentators recognized, have their own geometries even in the presentation of passion in action. We might add to their recorded remarks about the sweetness of the verse and the imitation of antique rules, the neatly parallel repetitions of danger and escape for both Silvia and Aminta, the reversal of roles so that she is athletic and he swooning, the graphically-full range of experience from her horizontal run to his vertical fall. Beyond all these, splendid intermedii regularly interrupted the performances, perhaps dwarfed and surrounded them. ${ }^{36}$

In the final act, Elpino gives credit for the happy solution to Love, who seems momentarily like a sophisticated landscape designer or playwright, "Con quant'arte / e per che ignote strade egli conduce / l'uomo ad esser beato" (5.1. 5-7). Elpino's conclusion directs the audience to see the scene as a whole, ultimately ordered despite the momentary confusions experienced on 
the way to the final triumph. The Aminta begins with flamboyant panoramas drawn from Ariosto and Ovid and works by leaps and bounds to the realism of the final, conventional worlds suggested by the description of the doting grandfather in the play and by the epilogue of the loving mother in the frame. These contexts of generations and gods, literary wit and elegant style expand the audience's perception beyond a mere appreciation of passion or, indeed, any single point of view. Many of these styles and attitudes are neither naive nor sentimental, whose only voice is Aminta's. The success of passion, the sorrow of growing old, the vindication of advice from the experienced, the silliness of youthful hyperbole provide themes for every heart. Tasso used them within a design affirming the pleasant comfort of calculated order.

At the same time that Tasso was writing the Aminta, he was also working on the first version of the Gerusalemme Liberata. In the epic, the design of the garden scenes resembles the settings in this pastoral play. The dream of Goffredo, the warnings of the old man of Ascalona, the eventual awakening and disgust of Rinaldo, Armida's hysterical and savage destruction of her garden all provide contexts that help organize the reader's right moral response to her garden. From the clarity of these designs, the reader could more readily interpret the threats lurking in the apparently lovely scene of the labyrinthine palace, its bird singing the pagan song of carpe diem, the arrogance of Armida dressed like a peacock and wearing the girdle of Venus, the stories on the gates illustrating the embarrassment of Hercules and the fall of Anthony because of lust. Even the solution of the epic which shows Armida rendering the Virgin's line, "Ecco l'ancilla tua" (20. 136.7) resembles the pastoral design of yoking together extraordinarilydivided characters into final, conventional harmonies. Like the misinterpreted scenes of the Aminta, the false garden of Armida makes visual the lesson that passion, by narrowing vision, ${ }^{37}$ leads to comic mistakes or tragic sorrows.

In the Aminta passion sends characters to the purlieus of the play, where the worst (the satyr) remain and from which the best return to families, marriage, the joys of the present and the promise of the future. The route to these great amplifying contexts, supported by literary allusions, is similar in both play and epic. Missing from the sight of the pastoral lovers and of Armida until the end, these broader concerns of moral decorum and 
literary elegance differentiate the author from the confusion he described. Similarly, poems praising actual princely retreats, which so resemble superficially the designs and illustrations of the perilous gardens of romance, continually reminded the observer of virtuous orders that seemed explicit to the surveyor. In his sonnet on the Belvedere and the Duchess Margharita who lived there, Tasso carefully distinguished the heavenly gardens of her court from the dangerous traps of Circe. ${ }^{38}$ Thus by implication or statement Tasso's pastoral play, lyric and epic supported the ideal of a golden age of virtuous moderation, triumphing over scenes from the wilder topographies of the soul.

To reach this conclusion, which flattered and unified the audiences in an appreciation of their civilized communities, Tasso expanded the scenery of passion into a major element in the Aminta. His playful designs require an agility of perception similar to that of Renaissance commentators who discovered arguments for order in the savage scenes of ancient satyric drama and to that of Ferrarese designers who used mountains and wildernesses as illustrations of princely power. The oscillations of the play's settings and styles illustrate the need for discrimination, an awareness of the whole picture, and the advantages of settled rule.

University of Oklahoma, Norman

JAMES J. YOCH

${ }^{1}$ Ovid, Metamorphoses, Loeb Classical Library, II (London: Harvard University Press, 1968): "quodcunque habitabile tellus / sustinet, huius erit: pontus quoque serviet illi!" (15. 830-31). For tapestries, see F. Gibbons, "Ferrarese Tapestries of Metamorphoses," Art Bulletin, 48 (1966), 409-11. Tasso's line, usually read as praise of Alfonso II, "a me quest' ozio ha fatto un dio" (2:2 271), repeats Virgil's "deus nobis haec otia fecit" (Eclogues 1.6, in The Eclogues and Georgics of Virgil, trans. C. Day Lewis (New York: Anchor, 1964). Quotations from the Aminta (and line references) herein are from Tasso, Poesie, ed. Francesco Flora, (Milan: Ricciardi, 1952). Sabadino praised Ercole d'Este as a new Augustus for expanding the capital and improving its monuments; see Werner L. Gundersheimer, Ferrara, The Style of a Renaissance Despotism (Princeton: Princeton University Press, 1973), p. 265.

${ }^{2}$ See Elizabeth MacDougall, "Ars Hortulorum: Sixteenth Century Garden Iconography and Literary Theory in Italy,' in The Italian Garden (Washington, D.C.: Dumbarton Oaks, 1972) pp. 44-45, who observes that 
the Ferrarese originated informal planting. E. Carrara, La Poesia Pastorale (Milan: F. Vallardi, 1908), p. 371, argued that the chivalric romances supplied the pastoral with curiously-knotted plots.

${ }^{3}$ Paolo Giovio catalogued Dosso of Ferrara's subjects: “ jagged rocks, green groves, the firm banks of traversing rivers, the flourishing work of the countryside, the gay and hard toil of the peasants, and all the far distant prospects of land and sea, fleets, fowl hunting and all that genre so pleasing to the eye in a lavish and festive style," quoted in E. H. Gombrich, "The Renaissance Theory of Art and the Rise of Landscape," in Norm and Form (London: Phaidon, 1966), pp. 113-14; David R. Coffin, The Villa d'Este at Tivoli (Princeton: Princeton University Press, 1960), pp. 79-82, 86-92, analyzed the plot of Ippolito d'Este's garden, which led from the lower levels and images of passion and Venus to the lofty authority of the villa and the triumph of Diana; see also Carl Lamb, Die Villa d'Este in Tivoli (Munich: Prestel-Verlag, 1966), pp. 93-95; Montaigne, Complete Works, trans. D. Frame (London: Hamish Hamilton, 1958), p. 964, thought of this garden as an outpost of Ferrarese power, for he continually referred to it as "Ferrara."

${ }^{4}$ Elizabethan Poetry (Cambridge, Mass.: Harvard University Press, 1954), pp. 15-16.

${ }^{5}$ For examples of commentaries on the play's sensual beauties see: W. W. Greg, Pastoral Poetry and Pastoral Drama (1905; rpt. New York: Russell and Russell, 1959), p. 179, 193; Giosuè Carducci, Su l" "Aminta"'di T. Tasso, saggi tre (Florence: Sansoni, 1896), p. 1; "l'idealizzazione ... della sensualità voluttuosamente malinconica"; Bruno Maier, ed., Torquato Tasso, Opere (Milan: Rizzoli, 1963), I, 30, notes similarly "un oscuro presagio d'inevitabile infelicità e, per contrasto, un'inclinazione edonisticamente epicurea"; J. A. Symonds, Italian Literature (1881; rpt. New York: Capricorn, 1964), II, 210. For the natural setting of the play see: Francesco De Sanctis, The History of Italian Literature, trans. J. Redfern (1931; rpt. New York: Barnes and Noble, 1968), II, 674. C. P. Brand, Torquato Tasso, A Study of the Poet and his Contribution to English Literature (Cambridge: Cambridge University Press, 1965), p. 47; Marvin Herrick, Tragicomedy (Urbana, Ill.: University of Illinois Press, 1962), p. 128; Peter Marinelli, Pastoral (London: Methuen, 1971), p. 25. Gaetano Trombatore, Saggi critici (Florence: La Nuova Italia, 1950), p. 133, described the world of the Aminta as "un felice albergo, risonante di dolci e canore voci di cigni, di ninfe e di sirene celesti."

More subtly, several critics have mentioned but not pursued the possibility of comic and ironic dimensions in the play. For example, see: Dominco Vittorini, "Realistic Elements in Tasso's Aminta: A Revision," Italica, 25 (1948), pp. 126-28; Renato Poggioli, "The Oaten Flute," Harvard Library Bulletin, 11 (1957), 158-59, recognized that in the close of 
the first chorus' description of the golden age Tasso repeated a line found in Dante's Inferno; more extensively, Mario Fubini, 'L'Aminta intermezzo alla tragedia della Liberata," in Studi sulla letteratura del rinascimento (1967; rpt. Florence: La Nuova Italia, 1971), p. 213, noted "Anche la sensualità, a parte il coro, che è soltanto una voce fra le altre voci della favola, non dev'essere così fortemente sottolineata come han fatto taluni critici"; Giorgio Bàrberi Squarotti, ed., Aminta (Padua: R.A.D.A.R., 1968), p. 14, claimed that the play taught "il carattere autodistruttivo della passione amorosa"; Richard Cody, The Landscape of the Mind (Oxford: Clarendon Press, 1969), p. 44, observed in the Aminta "all the classic symptoms of tragic love ... present under a serio-comic aspect"; Louise Clubb, "The Making of the Pastoral Play," in Petrarch to Pirandello, ed. J. A. Molinaro (Toronto: University of Toronto Press, 1973) pp. 61, 70-72, argues that Tasso eliminated the "comic discord of styles" once available in pastoral drama. Mario Fittoni, "Intorno all'ordito classico dell'Aminta," Convivium, 29 (1961), 12-20, reviewed criticism of the Aminta.

- Boccalini, in Menagio, sig. i4"; Manso, Vita di Torquato Tasso (Venice, 1621), sig. [B10] $]$-[B11]; Virginio Almerici, after a performance in Urbino (February, 1574), noted "la novità del coro fra ciascuno atto, che rendeva maesta mirabile, e recava con piacevolissimi concetti," quoted in Carducci, p. 96; when Tasso's friend, Angelo Ingegneri, Della poesia rappresentativa (Venice, 1598), sig. E2 ${ }^{v}$, summarized his rules for pastoral, he concentrated on formal designs rather than explosive emotions, for he recommended the audience should leave the theatre "con buone parole, \& con sonoro numero, \& con maniera gratiosa."

'Isaac Casaubon, Della satirica poesia de'Greci, e della satira de'Romani (Florence, 1728) sigs. O-O' ${ }^{\mathrm{v}}$; Giusto Fontanini, L'Aminta . . . difeso e illustrato (Venice, 1730) sig. G8v. G. B. Guarini, Il Pastor Fido e il compendio della poesia tragicomica (Venice, 1602) sigs. A4-A4 ${ }^{\mathrm{v}}, \mathrm{B} 5$, cited the Cyclops and the Amphitruo as models. See also Carrara, Pastorale, p. 322.

I have used "pastoral" in this paper in the sense Guarini describes of "drama dealing with shepherds" (Compendium, trans. A. H. Gilbert, Literary Criticism: Plato to Dryden, Detroit: Wayne State University Press, 1962, p. 532) especially in tragicomic form, which L. Clubb, in Italian Plays (1500-1700) in the Folger Library (Florence: Olschki, 1968), pp. xxxiv-xxxv, defined as prevailing in Ferrara.

Euripides, ed. Arthur S. Way, Loeb Classical Library, (London: Macmillan, 1912), II, 517.

' Euripides, Tragoediae (Basel, 1562), sig. T-T²; Stiblinus' commentary was often reprinted in editions of Euripides. Casaubon, Sig. O. 
${ }^{10}$ Stiblinus, sig. $\mathrm{T}^{\mathrm{v}}$; Philip Melancthon, Euripides Tragoediae (Frankfurt, 1562), sig. Aa2, wrote of the Cyclops: "Hac Tragoedia est imago tyrannis alicuius crudelissimi.",

11 Stiblinus, sig. $\mathrm{T}^{\mathrm{v}}$; similarly, Casaubon, Della Satirica, sig. $\mathrm{O}^{\mathrm{v}}$, described Ulysses as "non solamente prudente, e da bene, ma talvolta della virtù, e della pietà, alla filosofica più che altro.",

${ }^{12}$ Plautus, Comoedia (Venice, 1530) sig. [H7]-[H7] ${ }^{v}$; Plautus, Comoediae (Antwerp, 1566) sig. D2v'; Plautus' Comedies (London, 1694) sigs. F, F8 ${ }^{\mathrm{v}}$.

${ }^{13}$ S. Gaselee, Achilles Tatius, Loeb Classical Library (London: W. Heinemann, 1917), pp. $\mathrm{x}$-xi, quoted an epigram from the Palatine Anthology (9. 203) and summarized its meaning: "the real point of the epigram is that the reader is not to allow himself to be distracted by any of the incidents of the novel but to profit by the lesson of the main plot, which is undoubtedly, considered as a whole, a panegyric of chastity."

${ }^{14}$ Tatius, pp. 49-55. Dafne makes more realistic Clitophon's exotic examples of palms so loving they must be intergrafted, rivers marrying seas, land snakes and sea serpents, all creatures that must overcome extraordinary obstacles to mate (1. 16).

15 Tatius, pp. 67-69 (2. 7); Aminta, 1.2 350-448. Tasso's practice is consistent with the development of pastoral discussed by Ettore Bonora, "La teoria del teatro negli scrittori del ' 500 ," in Il teatro classico italiano nel '500 (Rome: Accademia Nazionale dei Lincei, 1971) pp. 245-51.

${ }^{16}$ When John Evelyn, The Diary of John Evelyn (London: Oxford University Press, 1959), p. 202, visited the Este villa at Tivoli, he recognized the organization of the Ovidian scenes leading to the model of the city of Rome; this garden plot repeats the plan of the Metamorphoses; I. I. Boissard, Romanae Vrbis Topographiae, (Frankfurt, 1597), I. 94, wrote of the Este garden on the Quirinal: "quibus nulli Romae videntur arborum diuersarum cultu spledidores, \& aedificio mirabilis artificii, quod ex arboribus consertis simul, \& implicatis Labyrinthum efficiunt.

${ }^{17}$ G. Pazzi, Le 'Delizie Estensi"' e l'Ariosto (Pescara: Riviera, 1933) pp. 257-64, quoted descriptions of several mountains ornamenting gardens. Angelo Solerti, Ferrara e la corte Estense (Città di Castello: S. Lapi, 1900) pp. xii-xiii, attempted to verbally reconstruct the montagna. Tasso, "A la Montagna di Ferrara," in Le Rime, (Bologna: Romagnoli dall'Acqua, 1900), III, 126-30, enriched the image of the mountain with classical gods and compared its flowered slopes to members of the Este family.

${ }^{18}$ Francisco Colonna, Hypnerotomachia Poliphili (Venice, 1499) sigs. h2 ${ }^{\mathrm{v}}$-h3. For the sources of Colonna's figure, see Giovanni Pozzi and Lucia A. Ciapponi, eds., Hypernotomachia Poliphili (Padua: Antenore, 1964), II, 120-21. Clubb, "The Making," pp. 58-65, describes the metaphoric use of the intrigue plot and settings such as the labyrinth of love and the dark wood. 
${ }^{19}$ Marc Antonio Guarini, MS, in Pazzi, p. 259; MacDougall, "Ars Hortulorum," p. 45, notes the informality of this planting, admittedly described as 'senz'ordine' (Pazzi, p. 259). But her argument is not concerned with the mountain's context: the perspective avenue leading from the town through a triumphal arch, the ordered beds and delicate flowers that put the scene within the theatre of princely power.

${ }^{20}$ "Io la trovai / là presso la cittade in quei gran prati / ove fra stagni giace un'isoletta"' (2.2 131-33).

${ }^{21}$ Boschini, MS, in Pazzi, p. 41, noted that the water jokes play "a voluntà del principe"; Lawrence Schrader, Ferrariae Urbis Descriptio et Monumenta, in Thesaurus Antiquitatum et Historiarum Italiae, (Lyon, 1722), I, sig. E4, observed that the garden had: "Balineum cum ponte, per quem incautius ambulantes in aquam decedunt." Faustini, in Menagio, sigs. [Kk3]-[Kk3] . Solerti, Ferrara, published as a centerfold a large and detailed map of Ferrara in 1597; the plan of the Belvedere conforms to surviving descriptions.

${ }^{22}$ For examples, see: Antonio Ongaro, L'Alceo (Ferrara, 1614); G. B. Guarini, Il Pastor Fido (Venice, 1602); Tasso, Aminta (Paris, 1655).

${ }^{23}$ Tasso, Aminta (Venice, 1590) sigs. A, Dv, [K4]. The plates are reused or copied in later editions such as the Aminta (Viterbo, 1632). Guarini had illustrations that included huts and a circular temple in the first scene, a tempietto in the second.

${ }^{24}$ F. P. Wilkinson, Ovid Recalled (Cambridge: Cambridge University Press, 1955), p. 397.

${ }^{25}$ Carducci, p. 87; Menagio, p. v.

${ }^{26}$ Giuseppe Agnelli, Ferrara e Pomposa (Bergamo: Instituto Italiano d'Arti Grafiche, 1902), pp. 70-72; Manso, Vita, sig. [B11] $]^{\mathrm{v}}$, wrote that Tasso included parts "il che fece egli a voluntà del Duca Alfonso, e forse ad imitatione de gli antichi compositori dell'Egloghe."

${ }^{27}$ Carrara, p. 332; Carducci, p. 80.

${ }^{28}$ Orfeo, 106, in Poesie Italiane, ed Saverio Orlando (Milan: Rizzoli, 1976). Maier, in T. Tasso, Opere, lists other possible sources of this commonplace argument from impossibility $(\mathrm{I}, 95)$.

${ }^{29}$ Ingegneri, sig. [E4]; Quintillian, Institutes, 6. 3. 67, connected jokes and hyperboles.

${ }^{30}$ Imitators of the Aminta continued this design of humor based on scorn of extravagance: in L'Alceo, the hero leaps into the sea; in $L^{\prime}$ Amoroso Sdegno Armillio jumps into a cage of wild animals. Rescues and embraces quickly follow.

Tasso's conclusion is the opposite of the violent separation that Leo Marx, The Machine in the Garden (1964; rpt. Oxford: Oxford University Press, 1968), p. 364, observes in the American pastoral: "in the end the American hero is either dead or totally alienated from society . . . The 
resolutions of our pastoral fables are unsatisfactory because the old symbol of reconciliation is obsolete."

${ }^{31}$ Greg, p. 183; Menagio, sigs. Uu-Uu2, complained that Tasso's narration weakens the impact of the lovers' embraces, since "imagini delle cose entrano nell'animo per la via de gli orecchi, non con tanta forza, quanto entrano per via de gli occhi'"; Cody, Landscape, p. 73, claimed that the brevity of the act suits the esoteric and self-deprecating style of pastoral.

32 “Dio" (2.2. 271), “celesti dee" (1.2 535), "la gran cittade in ripa al fiume" (1.2 479), "il felice albergo"' (1.2.520).

${ }^{33}$ Herrick, p. 129.

${ }^{34}$ Ingegneri, sigs. C2-D; he also observed that choruses add elegance to tragedies as the intermedii "arricchiscono lo spettacolo" of pastorals and comedies (sig. D); Tasso employed both choruses and intermedii; Claudio Varese, "L'Aminta," in Pascoli politico, Tasso e altri saggi (Milan: Feltrinelli, 1961), pp. 147-51, summariced arguments on the composition of the choruses and their contribution of "un significato universale, nobile, ideale alla vicenda di Aminta e di Silvia"; Tasso wittily used choruses to enrich his play and simultaneously to argue for simplicity.

${ }^{35}$ Only one edition (Ferrara, 1581) in Tasso's lifetime attaches the "Amor Fuggitivo" to the play, though some performances did (T. Tasso, Opere, ed. Maier, I, 197).

${ }^{36}$ For example, Carducci, pp. 97-98, quoted Filippo Baldinucci's description of Bernardo Buontalenti's magnificent staging of the Aminta in 1590 for the court of Ferdinand I, Grand Duke of Tuscany.

${ }^{37}$ A. Bartlett Giamatti, The Earthly Paradise and the Renaissance Epic (Princeton: Princeton University Press, 1966), p. 199. For a helpful analysis of "un anarchico edonismo" illustrated in the garden of Armida, see Ferruccio Ulivi, "I giardini del Tasso," in Il Giardino Storico Italiano, ed. Giovanna Ragionieri (Florence: Leo S. Olschki, 1981), pp. 309-18.

${ }^{38}$ In "Loda Belvedere e la signora Duchessa di Ferrara che vi abitava," Le Rime, IV, 36-37, Tasso contrasted Circe, who turned men into beasts with the Duchess who: "Ma più tosto li rende a Dio sembianti, / Tanta ne le dolcissime parole / Virtù raccoglie e ne' begli occhi santi / La figlia del'eterno e sommo Sole." 